Research article

\title{
ATIPAMEZOLE ATTENUATED TELAZOL/ XYLAZINE-INDUCED EXPRESSION OF C-FOS IN RAT THALAMENCEPHAL AND CEREBRAL CORTEX
}

\author{
BAI-SHUANG Yin ${ }^{1,3}$, LI $\mathrm{GaO}^{2}$, LIAN-JUN Fu${ }^{1}$, YING Fu${ }^{1}$, WAN-LI Sha ${ }^{1,3}$, \\ GUO-JIANG Li ${ }^{1,3}$, HONG-BIN Wang ${ }^{2 *}$
}

${ }^{1}$ Department of Veterinary Science, Jilin Agriculture Science and Technology College, Jilin 132101, China.${ }^{2}$ College of Veterinary Medicine, Northeast Agricultural University, Harbin 150030, China, ${ }^{3}$ Key Lab of Preventive Veterinary Medicine in Jilin Province, Jilin 132101, China

(Received 02 June; Accepted 22 September 2016)

\begin{abstract}
The aim of this study was to assess whether atipamezole can restrain telazol/xylazine induced expression of c-fos in the rat brain. Rats were injected with a mixture of 13.81 $\mathrm{mg} / \mathrm{kg}$ telazol and $5.21 \mathrm{mg} / \mathrm{kg}$ xylazine, following $10 \mathrm{~min}$ later $0.522 \mathrm{mg} / \mathrm{kg}$ atipamezole. Thereon, the thalamencephal and cerebral cortex were removed one hour after the last injection. The level of Fos protein was measured in the brain tissue by Westernblot. The results revealed that atipamezole attenuates telazol/xylazine induction of c-fos expression in the thalamencephal and cerebral cortex. The results indicated that atipamezole is able to inhibit telazol/xylazine-induced c-fos expression in the rat brain, thus protecting it from nerve damage.
\end{abstract}

Key words: atipamezole, telazol, xylazine, rat, c-fos, brain

\section{INTRODUCTION}

Xylazine is an $\alpha_{2}$-adrenergic receptor agonist. It contributes short duration analgesia, sedation, and muscle relaxation. Telazol contains a 1:1 combination of tiletamine and zolazepam. Tiletamine is a dissociative agent that produces analgesia, immobilization, and with increasing dose general anesthesia. Zolazepam is a benzodiazepine with anxiolytic and muscle relaxant properties. Advantages of telazol include a high therapeutic index, minimal respiratory effects, and a good cardiovascular support [1]. Hence, telazol as a sole immobilizing agent and in combination with xylazine is used to immobilize wildlife [2-4], cats [5], dogs [6], and livestock [7,8]. Telazol-xylazine has been used on several animal species including white-tailed deer [9], bighorn sheep [10], grizzly bears [11], raccoons [12], American martens [13], and martes pennanti [14]. Atipamezole is a potent and selective $\alpha_{2}$-adrenoceptor agonist with a competitive nature which can antagonize ketamine [15], reverse xylazine-ketamine anaesthesia in

*Corresponding author: e-mail: hbwang1940@163.com 
the Northern chamois [16], reverse medetomidine -ketamine and tiletamine-zolazepam restrained fishers $[17,18]$.

Anesthesia reduces nerve cell metabolism in the central nervous system (CNS) resulting in nerve cell damage. Thus a reasonable use of a narcotic antagonist to awake the anesthetized animal may protect nerve cells. The c-fos is a member of the immediate early gene family. C-fos expresses the Fos protein which dimerizes with the Jun protein to form the activator protein-1(AP-1). AP-1 acts as a transcriptional factor binding to DNA thereby regulating the expression of nearby promoters. C-fos activation has been proposed as a marker of neuronal injury since its induction is promoted by abnormal brain function, including neuronal plasticity and delayed neuronal death [19,20]. The c-fos expression studies have given evidence that c-fos expresses Fos protein rapidly and transiently within neurons after many types of stimulation, such as physiological stimuli, chemical agents and transmitter agonists [19,21]. It has been proposed that c-fos may function as a third messenger in an intracellular cascade linking extracellular stimuli to long-term adaptive processes [19,22]. C-fos gene expression is rapidly and transiently induced in many cell types for signaling late-response genes that generate functional proteins [19,23].

The purpose of this experiment was to determine, by using c-fos Western blot as a dependent variable, whether a selective antagonist such as atipamezole can restrain telazol-xylazine induced expression of $\mathrm{c}$-fos in the brain.

\section{MATERIALS AND METHODS}

\section{Reagents and instruments}

Atipamezole (Antisedan, Orion Corporation Farmos Turku, Finland), xylazine (Bayer Co., Germany), telazol ${ }^{\circledR}(100 \mathrm{mg} / \mathrm{mL}$, Fort Dodge Animal Health, Fort Dodge, IA, USA), rabbit anti-rat polyantibody and goat anti-rat IgG (Sigma, USA), radioimmunoprecipitation assay Lysis Buffer, BeyoECL Plus and bicinchoninic acid were purchased from China. All the other chemical reagents used were of the highest grade commercially available in China. The protein electrophoresis system (Baygene Co., China), ChampGel picture processing system (Sagecreation Co., China).

\section{Animals and grouping}

Twenty male and female Sprague-Dawley rats weighing approximately $180-200 \mathrm{~g}$ were used in the experiment. The experimental procedures were performed in accordance with the Jilin province Committee for Animal Experiments. The animals were housed at a controlled temperature $\left(20 \pm 2^{\circ} \mathrm{C}\right)$ and maintained under light-dark cycles, each consisting of $12 \mathrm{~h}$ of light and $12 \mathrm{~h}$ of darkness (lights on from 06:00 to 18:00 h), with food and water made available ad libitum. In order to minimize stress-induced changes in c-fos expression in subsequent experiments the rats were handled (the lower 
abdomen was pierced with an injection needle, but no injection) for more than 5 days. The sixth day, the rats were injected with drugs. Rats were divided into four groups: 50\% Dimethyl Sulphoxide (DMSO) administrated group as the control, telazol administrated group, telazol/xylazine administrated group, atipamezole-telazol/ xylazine administrated group ( $\mathrm{n}=5$ in each group).

\section{Sampling procedure}

Rats were given 50\% DMSO in the control group. Each rat was given the mixture of $13.81 \mathrm{mg} / \mathrm{kg}$ telazol and $5.21 \mathrm{mg} / \mathrm{kg}$ xylazine followed 10 min later by $0.522 \mathrm{mg} /$ $\mathrm{kg}$ atipamezole intraperitoneal injection in the experiment group. About $1 \mathrm{~h}$ later, the rats were decapitated, the cerebral cortex and thalamencephal were dissected on ice and frozen, and stored overnight at $-70^{\circ} \mathrm{C}$. Total proteins were extracted with radioimmunoprecipitation assay in lysate buffer. The concentration was determined with the bicinchoninic acid kit.

\section{Western blot}

The method was referred by Niles and Smith [24], and slightly modified. Protein samples were diluted (1:4) with sample buffer (Beyotime Biotechnology) and boiled at $100{ }^{\circ} \mathrm{C}$ for $5 \mathrm{~min}$. protein samples $(20 \mathrm{mg}$ ) were subjected to sodium dodecyl sulfate polyacrylamide gel electrophoresis (5\% stacking gel, 12\% separating gel), electrified $2.5 \mathrm{~h}$ at $80-120 \mathrm{~V}$. The gel was equilibrated in transfer buffer $(\mathrm{pH} 8.3 ; 25$ $\mathrm{mM}$ Tris $/ 20 \%$ methanol $/ 20 \mathrm{mM}$ glycine), separated proteins were transferred 170 $\mathrm{min}$ at $150 \mathrm{~mA}$ to polyvinylidene difluoride membranes. Subsequently, non-specific binding sites were blocked by incubation with $5 \%(\mathrm{w} / \mathrm{v})$ non-fat dry milk freshly prepared in Tris-buffered saline containing 0.05\% (v/v) 140 Tween-20 (TBST) for $2 \mathrm{~h}$ at room temperature. polyvinylidene difluoride membranes were then incubated with a similar solution containing a primary rabbit anti- $c$-Fos antibody overnight at 4 ${ }^{\circ} \mathrm{C}$. After three washes with TBST, the membranes were incubated with horseradish peroxidase (HRP) -conjugated goat anti-rabbit IgG for $1 \mathrm{~h}$. After washing four times in TBST, the signals were visualized using enhanced chemiluminescence (ECL) for 1 min, and then exposed to ECL hyperfilm in the dark for periods ranging from 20 s to $1.5 \mathrm{~min}$. The film was washed and band intensities measured by densitometry. Optical density values of Fos protein was divided by the protein concentrations of $\beta$-action. Subsequently, data were converted to percentage values.

\section{Statistical analysis}

All the experiments were repeated for 5 times. Results were presented as mean \pm s. One-way ANOVA was used for group comparison, $P<0.05$ was considered to be significant and $P<0.01$ was considered to be extremely significant. 


\section{RESULTS}

As shown in Fig. 1 and Fig. 2, intrabdominal cavity administration of telazol (13.81 $\mathrm{mg} / \mathrm{kg}) /$ xylazine $(5.21 \mathrm{mg} / \mathrm{kg})$ caused an extremely significant induction of c-fos expression in the thalamencephal and cerebral cortex of rats during the period of anesthesia, compared with the control group $(P<0.01)$. The administration of atipamezole $(0.522 \mathrm{mg} / \mathrm{kg})$ caused an extremely significant attenuation of telazol/ xylazine induction of $\mathrm{c}$-fos expression in the same brain regions $(P<0.01)$. The results showed that not only atipamezole may wake up rats anesthetized by telazol/xylazine, but can also inhibit c-fos gene expression in the rat brain.
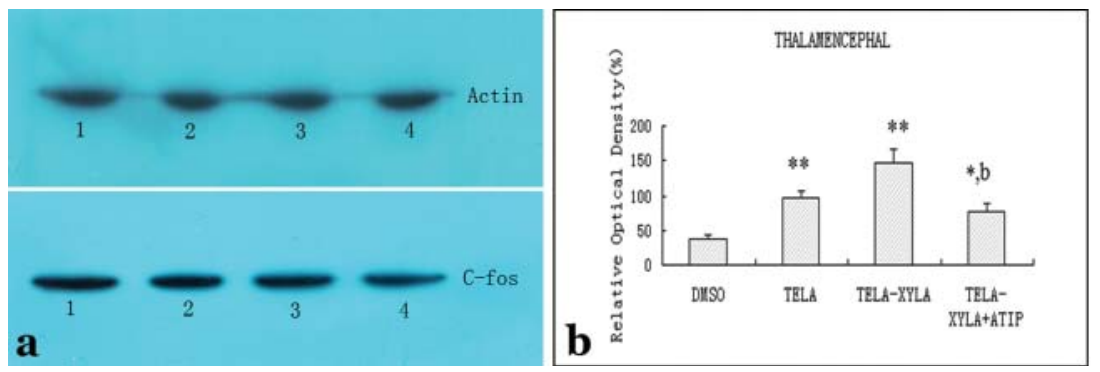

Fig.1. Effects of atipamezole and telazol/xylazine on Fos expression in the cerebral cortex. (A) Representative autoradiogram of Fos protein in the cerebral cortex. Lane 1, Control (50\% DMSO); lane 2, telazol group; lane 3, telazol/xylazine group; lane 4, telazol/ xylazine+atipamezole group. Protein load: $20 \mathrm{mg}$ per lanes 1-3, respectively. (B) Representative changes of Fos protein in cerebral cortex. Data are given as mean $\pm \mathrm{s}(\mathrm{n}=5)$ of optical density values, corrected for protein loaded per lane, and presented as a percentage of control. $\beta$-actin, Fos-related antigen. $* \mathrm{P}<0.05$ and $* * \mathrm{P}<0.01$ versus control (Student's t-test); $\mathrm{b}$ indicates $\mathrm{P}<0.01$ versus TELA-XYLA (Student's t-test).
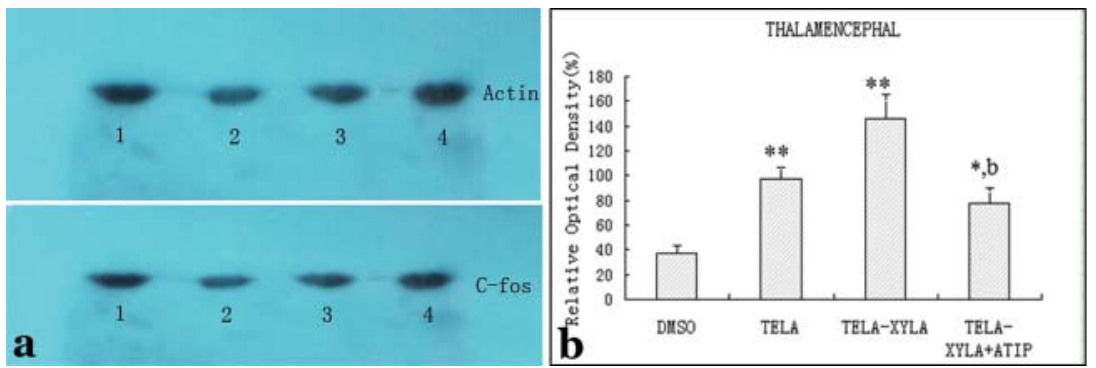

Fig.2. Effects of atipamezole and telazol/xylazine on Fos expression in the thalamencephal. (A) Representative autoradiogram of Fos protein in the thalamencephal. (B) Representative changes of Fos protein in the thalamencephal.

\section{DISCUSSION}

Telazol is a fixed-ratio combination of zolazepam with tiletamine, used for injection anesthesia in dogs, cats, wild and zoo animals [25]. Tiletamine is a dissociative anesthetic 
similar to ketamine and phencyclidine, and zolazepam is a diazepine derivative tranquilizer used to minimize the muscle hypertonicity and seizures associated with tiletamine [26]. Xylazine has been used as a component of a variety of anaesthetics in domestic and wild animals in developing countries [27,28], xylazine was also a better option for premedication in dogs during a prolonged surgical intervention [29]. Telazol-xylazine has been used for injection anesthesia in several animal species. In the past some researchs have also reported that, after $1 \mathrm{~h}$ of urethane anesthesia, Fos-ir neurons were found in 12 nuclei in the CNS [30]. The $\alpha$-Chloralose, halothane and sodium pentobarbital have induced Fos expression in the brain $[1,31]$. The haloperidol increased c-fos expression in the striatum [32]. The experiment indicated that the telazol/xylazine inducted $c$-fos gene excessive expression in the thalamencephal and cerebral cortex. Over-expressing $c$-fos gene has been promoted as a marker of neuronal injury [14]. However, during the course of telazol/xylazine anesthesia, rat brain injury may be possible. So it is necessary to inject an appropriate antagonist at the appropriate time to terminate telazol/xylazine anaesthesia and inhibit the telazol/xylazine induced expression of Fos.

Atipamezole is an $\alpha_{2}$-adrenoceptor antagonist with an imidazole structure as synthesized by Orion Pharma Ltd., Turku, Finland [20]. It has no species-specific differences in its effects [23]. In the study of central nervous system functions, atipamezole provides a highly specific, selective and potent tool for blocking central $\alpha_{2}$-adrenoceptors. In veterinary practice, atipamezole has proved useful in rapidly reversing anesthesia, immobilization and undesirable side effects induced by $\alpha_{2}$-adrenoceptor agonists alone or in combination with other anesthetics [33]. Additionally, atipamezole- precipitated clonidine withdrawal can induce c-fos expression in rat CNS [34]. The experiment found that administration of atipamezole not only could wake up rats anesthetized with telazol/xylazine, but is also able to inhibit telazol/xylazine-induced $c$-fos expression in the rat thalamencephal and cerebral cortex. Thus, atipamezole may reduce neuronal injury induced by anesthesia with telazol/xylazine.

The study found that the telazol/xylazine induced the expression of c-fos in the rat thalamencephal and cerebral cortex. Atipamezole may wake up rats anesthetized with telazol/xylazine, and is able to inhibit telazol/xylazine-induced $c$-fos expression in the thalamencephal and cerebral cortex, thus playing a protective role in neuronal injury.

\section{Acknowledgement}

This study was funded by the National Natural Science Foundation of China (Grants Nos. 31302150, 31272617 and 31572580).

\section{Authors' contributions}

BY carried out the Western-blot studies and finished the manuscript. LG carried out the monitored anesthesia care. LF participated in Western-blot studies. HW participated 
in the design of the study and helped to draft the manuscript. YF performed the statistical analyses. WS participated in sample collection and handle. GL participated in its coordinacion. All authors read and approved the final manuscript.

\section{Declaration of conflicting interests}

The author(s) declared no potential conflicts of interest with respect to the research, authorship, and/or publication of this article.

\section{REFERENCES}

1. Kiyoshige T, Takashi S, Mitsuhiko M: The comparison of effects of various anesthetics on expression of Fos protein in the rat brain. Neuroscience Letter 1994, 176(1): 59-62.

2. Mitcheltree DH, Serfass WM, Tzilkowski RL, Peper MT, Whary RP: Physiological responses of fishers to immobilization with ketamine, ketamine-xylazine, or Telazol. Wildlife Society Bulletin 1999, 27(3): 582-591.

3. Golden HN, Shults BS, Kunkel KE: Immobilization of wolverines with Telazol from a helicopter. Wildlife Society Bulletin 2002, 30(2): 492-497.

4. Janovsky M, Tataruch F, Ambuehl M, Giacometti M: A Zoletil®-Rompun ${ }^{\circledR}$ mixture as an alternative to the use of opioids for immobilization of feral red deer. Journal of Wildlife Diseases 2000, 36(4): 663-669.

5. Hellyer P, Muir WW, Hubbell JA, Sally J: Cardio respiratory effects of the intravenous administration of tiletamine-zolazepam to cats. Veterinary Surgery 1988, 17(7): 105-110.

6. Jang HS, Kwon YS, Lee MG, Jang KH: The effect of tiletamine/zolazepam combination with xylazine or medetomidine on electroencephalograms in dogs. Journal of Veterinary Medical Science 2004, 66(5): 501-507.

7. Natalini CC, Alves SD, Guedes AG, Polydoro AS, Brondani JT, Bopp S: Epidural administration of tiletamine/zolazepam in horses. Veterinary Anaesthesia and Analgesia 2004, 31(4): 79-85.

8. Lu DZ, Fan HG, Ma K, Jiang S, Wang HB: Effect of Addition of Tramadol to Tiletamine/ zolazepam-Xylazine Anaesthesia in Miniature Pigs. Veterinary Record 2010, 167(13): 489492.

9. Miller BF, Muller LI, Doherty T, Osborn DA, Miller KV, Warren RJ: Effectiveness of antagonists for tiletamine-zolazepam/xylazine immobilization in female white-tailed deer. Journal of Wildlife Diseases 2004, 40(3): 533-537.

10. Merwin DS, Milspaugh JJ, Brundige GC, Schultz D, Tyner CL: Immobilization of freeranging Rocky Mountain bighorn sheep, Ovis canadensis canadensis, ewes with Telazol ${ }^{\circledR}$ and xylazine hydrochloride. Canadian Field-Naturalist 2000, 114(3): 471 -475.

11. Cattet MR, Caulkett NA, Stenhouse GB: The comparative effects of chemical immobilizing drug and method of capture on the health of grizzly bears. Thirteenth International Conference on Bear Research and Management, Jackson, Wyoming 2001, 5: 20-26.

12. Belant JL: Belant Field Immobilization of Raccoons (Procyon lotor) with Telazol and Xylazine. Journal of Wildlife Disease 2004, 40(4): 787-790.

13. Belant JL: Tiletamine-zolazepam-xylazine immobilization of American marten (Martes Americana). Journal of Wildlife Disease 2005, 41(3): 659-663. 
14. Belant JL: Tiletamine-zolazepam-xylazine Immobilization of Fishers (Martes pennanti). Journal of Wildlife Disease 2007, 43(2): 279-285.

15. Jalanka HH, Roeken BO: The use of medetomidine-ketamine combinations, and atipamezole in nondomestic mammals: a review. Journal of Zoo \& Wildlife Medicine 1990, 21(3): 259-282.

16. Dematteis A, Menzano A, Canavese G, Meneguz PG, Rossi L: Anaesthesia of freeranging Northern chamois (Rupicapra rupicapra) with xylazine/ketamine and reversal with atipamezole. European Journal of Wildlife Research 2009, 55(6): 567 -573.

17. Jung SY, Kim MS, Lee NY, Kim SY, Seo KM, Nam TC: The reverse effects of atipamezole on medetomidine-tiletamine/zolazepam combination anesthesia in the green iguana (Iguana iguana). Journal of Veterinary clinics 2006, 23(1): 18-21.

18. Heaton-Jones TG, Ko JC, Heaton-Jones DL: Evaluation of medetomidine-ketamine anesthesia with atipamezole reversal in American alligators (Alligator Mississippi -ensis). Journal of Zoo \& Wildlife Medicine 2002, 33(1): 36-44.

19. Ezgi T, Lutfiye K, Ayfer Y: Effect of $\gamma$-glutamylcysteine ethylester on the levels of c-fos mRNA expression, glutathione and reactive oxygen species formation in kainic acid excitotoxicity. Journal of Pharmacy and Pharmacology 2010, 62(8): 1010-1017.

20. Sharp FR, Sagar SM: Alterationa in gene expression as an index of neuronal injury: heat shock and the immediate early gene response. Neurotoxicology 1994, 15(1): 51-59.

21. Dragunow M, Faull R: The use of c-fos as metabolic marker in neuronal pathway tracing. Journal of Neuroscience Methods 1989, 29(3): 261-265.

22. Griffiths R, Malcolm C, Ritchie L, Frandsen A, Schousboe A, Scott M, Rumsby P, Meredith C: Association of c-fos mRNA expression and excitotoxicity in primary cultures of mouse neocortical and cerebellar neurons. Journal of Neuroscience Research 1997, 48(6): 533-542.

23. Willoughby JO, Mackenzie L, Medvedev A, Hiscock JJ: Fos induction following systemic kainic acid: early expression in hippocampus and later widespread expression correlated with seizure. Neurosience 1997, 77(2): 379-392.

24. Niles LP, Smith LJ, Tenn CC: Modulation of $\mathrm{c}$-fos expression in the rat striatum by diazepam. Neuroscience Letters 1997, 236(1): 5-8.

25. Kumar A, Mann HJ, Remmel RP: Determination of constituents of Telazol ${ }^{\circledR}$-tiletamine and zolazepam by a gas chromatography/mass spectrometry-based method. Journal of Chromatography B 2006, 842(2): 131-135.

26. Lee CC, Lin YY, Hsu CW, Chu SJ, Tsai SH: Movement disorder caused by abuse of veterinary anesthesia containing tiletamine. American Journal of Emergency Medicine 2009, 27(8): 1022.e5-1022.e6.

27. Nieradko B, Borzecki A: Effect of bifenthrin on memory processes, movement activity, and coordination in mice exposed to transient cerebral oligaemia. Bulletin of Veterinary Institute in Pulawy 2008, 52(2): 291-294.

28. Yin BS, Wang HB, Gong DQ, Li GJ, Gao L: Effects of Xylazine on glutamate and GABA contents in the hippocampus and thalamencephal in the rat. Bulletin of Veterinary Institute in Pulawy 2011, 55(3): 537-539.

29. Lipták T, Capík I, Ledecký V, Nagy O, Kuricová M, Tóthová C, Mad Ad’ari A, Farbáková J, Petrovič V, Hornák S: Cardiorespiratory and hemodynamic effects of medetomidine or xylazine with atropine and diazepam premedication for total intravenous anesthesia induced and maintained with propofol/fentanyl in dogs undergoing surgery. Acta VeterinariaBeograd 2014, 64 (4): 466-476. 
30. Krukoff TL, Morton TL, Harris KH, Jhamandas JH: Expression of c-fos protein in rat brain elicited by electrical stimulation of the pontine parabrachial nucleus. Journal of Neuroscience 1992, 12(9): 3582-3590.

31. Shimode N, Fukuoka T, Tanimoto M, Tashiro C, Tokunaga A, Noguchi K: The effects of dexmedetomidine and halothane on Fos expression in the spinal dorsal horn using a rat postoperative pain model. Neuroscience Letter 2003, 343(1): 45-48.

32. Miller $\mathrm{J}$ : induction of $\mathrm{c}$-fos mRNA expression in rat striatum by neuroleptic drugs. Neurochemistry 1990, 54(4): 1453-1455.

33. Pertovaara A, Haapalinna A, Sirviö J, Virtanen R: Pharmacological Properties, Central Nervous System Effects, and Potential Therapeutic Applications of Atipamezole, a Selective $\alpha_{2}$-Adrenoceptor Antagonist. CNS Drug Reviews 2005, 11(3): 273-288.

34. Ruth LS, Michele CG, Patrice GG: Atipamezole-precipitated clonidine withdrawal induces c-Fos expression in rat central nervous system. Brain Research 1997, 764(1-2): 81-92.

\title{
ATIPAMEZOL - ATENUISANA TELAZOL/KSILAZIN - INDUKOVANA EKSPRESIJA C-FOS U TALAMENCEFALIČNOM I CEREBRALNOM KORTEKSU PACOVA
}

\author{
BAI-SHUANG Yin, LI Gao, LIAN-JUN Fu, YING Fu, WAN-LI Sha, \\ GUO-JIANG Li, HONG-BIN Wang
}

Cilj studije je bio procena da li atipamezol može da ograniči telazol/ksilazin - indukovanu ekspresiju c-fosa u mozgu pacova. Pacovima je ubrizgana mešavina 13,81 mg/ $\mathrm{kg}$ telazola i 5,21 mg/kg ksilazina. Nakon 10 minuta aplikovano je 0,522 mg/kg atipemezola, a nakon poslednje injekcije je sat kasnije pacovima uklonjen talamencefalični i cerebralni korteks. Nivo Fos proteina je izmeren u moždanom tkivu metodom Western blot. Rezultati su pokazali da atipamezol atenuira telazol/ksilazol indukciju ekspresije c-fos u talamencefaličnom i cerebralnom korteksu. Rezultati ukazuju da je atipemezol sposoban da inhibira telazol/ksilazin indukovanu ekspresiju c-fosa u mozgu pacova $i$ tako zaštiti nerve od oštećenja. 